\title{
Sosialisasi Akad-akad Ekonomi Syariah Pada BUMDes di Desa Kaotan Blimbingsari Banyuwangi
}

\author{
Abd. Rohman Fahruddin ${ }^{1 *}$, Deni Arifianto ${ }^{2}$ \\ ${ }^{1}$ Jurusan Ekonomi Syariah Universitas Muhammadiyah Jember \\ ${ }^{2}$ Jurusan Ilmu Komunikasi Universitas Muhammadiyah Jember \\ abdrohmanf@unmuhjember.ac.id,deniarifianto@unmuhjember.ac.id
}

\begin{abstract}
BUMDes is an instrument that drives the macro economy at the village level based on local potential and wisdom. Management of BUMDes in a professional manner can be a solution in order to advance and prosper all elements of village society. BUMDes Mitra Sejahtera is the BUMDes of Kaotan Blimbingsari village which has business activities in the form of buying and selling food and renting agricultural equipment. The management of Mitra Sejahtera BUMDes has been carried out on a traditional conventional basis. The majority of the people in Kaotan Blimbingsarivillage are Muslims with the value of mutual cooperation that thrives in the community.BUMDES business activities must be based on benefits and do not contain elements of persecution (tyranny) for the community.Departing from the spirit of doing changes for the better, the condition of the Kaotan village community and the principles of BUMDes business activities, the authors conclude that the implementation of the Sharia economic system is a solution for BUMDes Mitra Sejahtera. Therefore, the socialization of Islamic economic contracts is an important necessity for the managers of BUMDes Mitra Sejahtera. The socialization material includes Sharia business principles and forms of Sharia contracts. The implementation of this activity is packaged in a workshop. Activities carried out using the method of lectures, discussions and practices at the Kaotan Village-Owned Enterprise. This activity is carried out not once but through several stages in accordance with the material that has been compiled by the presenter
\end{abstract}

Keywords : BUMDes, Islamic Economic Contracts

\begin{abstract}
Abstrak
BUMDes merupakan instrument penggerak perekonomian makro di tingkat desa yang berbasis potensi dan kearifan local setempat. Pengelolaan BUMDes secara professional dapat menjadi solusi dalam rangka memajukan dan memakmurkan seluruh elemen masyarakat desa. BUMDes Mitra Sejahtera merupakan BUMDes desa Kaotan Blimbingsari yang memiliki kegiatan usaha berupa jual beli makanan dan sewa menyewa alat pertanian. Pengelolaan BUMDes Mitra Sejahtera selama ini masih dilakukan dengan basis konvensional tradisional. Kondisi sosial masyarakat desa Kaotan Blimbingsari mayoritas beragama Islam dengan nilai gotong royong yang tumbuh subur pada masyarakatnya. Kegiatan usaha BUMDes harus berasaskan manfaat dan tidak mengandung unsur aniaya (kedzoliman) bagi masyarakatnya. Berangkat dari semangat malakukan perubahan kea rah lebih baik, kondisi masyarakat desa Kaotan serta asas dari kegiatan usaha BUMDes, penulis menyimpulkan bahwa penerapan system ekonomi Syariah merupakan solusi dari BUMDes Mitra Sejahtera. Oleh karenanya pelaksanaan sosialisasi akad-akad ekonomi Syariah menjadi suatu kebutuhan penting bagi pengelola BUMDes Mitra Sejahtera. Adapun materi sosialisasi meliputi prinsip bisnis Syariah dan bentuk akad-akad Syariah.Pelaksanaan kegiatan ini dikemas dalam workshop. Kegiatan dilakukan menggunakan metode ceramah, diskusi dan praktek di Badan Usaha Milik Desa Kaotan. Kegiatan ini dilakukan bukan hanya sekali tetapi melalui beberapa tahapan sesuai dengan materi yang telah di susun oleh pemateri.
\end{abstract}

Kata Kunci: BUMDes, Akad Syariah

*Penulis Korespondensi : Abd. Rohman Fahruddin

http://comdev.pubmedia.id | Indonesian Journal Publisher | https://idpublishing.org

Hal 1 dari 9 


\section{PENDAHULUAN}

Munculnya Lembaga perekonomian desa yang berwujud Badan Usaha Milik Desa (BUMDes) dimaksudkan semata-mata untuk memajukan ekonomi masyarakat desa yang bersifat partisipatif, emansipatif, kolaboratif, akuntabilitas dan sustainable yang didasarkan pada potensi dan kearifan budaya local. Undang-Undang (UU) Nomor 23 Tahun 2014 tentang Pemerintah Daerah pada Pasal 213 Ayat (1) disebutkan bahwa dapat mendirikan Badan Usaha Milik Desa sesuai dengan kebutuhan dan potensi desa". Substansi UU ini menegaskan tentang janji pemenuhan permintaan (demand complience scenario) dalam konteks pembangunan di tingkat desa.

Pelaksanaan kegiatan pengelolaan sebuah perusahaan dengan prinsip dasar yaitu transparansi bermakna keterbukaan dalam menjalankan bisnis melalui penyediaan informasi yang aksesible dan relevan yang dapat dipahami oleh berbagai pihak. Akuntabilitas, terciptanya fungsi, pelaksanaan dan pertanggungjawaban oleh seluruh organisasi perusahaan. Independensi, kemandirian dan tidak terdapatnya intervensi oleh pihak lain terhadap organisasi perusahaan, sehingga dapat berjalan sesuai dengan tugas dan kewengan masing-masing. Kewajaran dan kesetaraan, melaksanakan prinsip kewajaran terhadap seluruh pemangku kepentingan, dan juga kesetaraan dalam menerapkan sikap kepada publik, pasar maupun pemegang saham.

Islam merupakan perwujudan agama komprehensif dengan upaya untuk mengatur seluruh aspek kehidupan manusia. Manusia sebagai khalifah Allah di muka bumi memiliki tanggung jawab dan memiliki amanah untuk memakmurkan bumi. Firman Allah dalam surat alBaqarah ayat 30 :

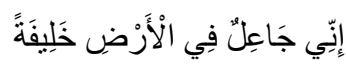

"Sesungguhnya Aku hendak menjadikan seorang khalifah di muka bumi"

Allah berfirman pada surat Hud ayat 61 :

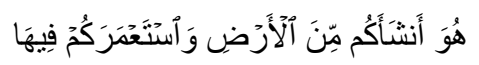
"Dia telah menciptakanmu dari bumi (tanah) dan menjadikanmu pemakmurnya."

Dalam mengolah dan memakmurkan bumi, Islam memberikan rambu berupa prinsip-prinsip yang sudah seharusnya menjadi pedoman dan panutan. Prinsip islam tentu mampu memberikan regulasi serta koridor yang baik bagi manusia dalam mengembangkan dan mengelola usaha yang dimiliki. Prinsip-prinsip maupun nilai-nilai islam tentu akan membawa keberkahan dan kehalalan kegiatan bisnis dan ekonomi. Tentu pengelolaan bisnis islam tidaklah jauh dari penerapan etika bisnis yang sesuai dengan Al Qur'an dan Hadits.

Upaya menerapkan Etika bisnis di dalam Islam lebih cenderung memunculkan sifat kejujuran, keterbukaan untuk setiap akad maupu transaksi di masing-masing pihak. Integrasi etika bisnis islam juga mendukung tata kelola bisnis serta memiliki nilai-nilai positif diantaranya, keadilan (adl), kebaikan (ihsan), amanah dan kesabaran (sabr). Tentu setiap bisnis yang dijalani oelh semua umat muslaim perlu dijauhkan dari hal-hal yang bersifat negative sepertihalnya spekulasi (maysir), ketidakjelasan (gharar), riba, dan berkebihlebihan (israf). Jika pengelolaan bisnis mengacu pada etika bisnis yang baik, sudah dapat dipastikan akan mendapatkan kebaikan didalamnya (Lewis, 2001).

Dari penelusuran peneliti yang dirangkum dalam berbagai sumber mitra, sebagian besar pengembangan serta pengelolaan BUMDes belum dapat dirasakan oleh masyarakat desa secara maksimal, beberapa hal itu antara lain:

1. Kurangnya tingkat pemahaman perangkat desa mengenai BUMDES, pemahaman perangkat desa yang lebih bersifat struktural dan administratif berdampak pada kurang marketablenya BUMDes sehingga terkesan elitis dan tidak aspiratif.

2. Lemahnya pembangunan SDM yang mampu mengelola BUMDes secara profesioanl sehingga mampu menjadikan BUMDes sebagai lembaga 
ekonomi masyarakat desa yang meberikan dampak positif bagi ekonomi rakyat.

3. Belum maksimalnya komunikasi antara perangkat desa dan masyarakat tentang isu-isu yang perlu mendapat respon. Sering terjadi bahwa banyak informasi hanya menjadi konsumsi elit perangkat desa dan tokoh masyarakat saja. akibatnya stuktruk BUMDES hanya dihuni oleh lingkar kekuasaan elit desa saja.

4. Gejala koruptif yang hampir menerjang di semua struktur kekuasaan juga memberi kontribusi terhadap perkembangan BUMDes. Sudah tidak terhitung lagi, berapa banyak kepala desa yang berurusan dengan Komisi Pemberantasan Korupsi.

5. Sumber daya manusia yang memiliki kemampuan manajerial yang professional untuk menahkodai BUMDes masih terbatas.

6. Kurangya daya tarik bagi sebagian kaum muda untuk terlibat dalam BUMDes, sebab seringkali muncul kekhawatiran bahwa BUMDes bukan tempat yang "asyik" dan menjanjikan bagi masa depannya.

7. Rendahnya tingkat literasi akad-akad syariah sehingga sering terjadi pengelolaan BUMDes masih tidak selaras dengan hukum Islam. Misalnya unit usaha simpan pinjam yang masih menggunakan sistem konvensional yang berpatok pada besaran bunga.

Di dalam sebuah transaksi bisnis syariah, keberadaan akad sangat menentukan aspek kepatuhan syar'inya. Sebab akad merupakan koridor utama dalam melakukan transaksi sesuai dengan syariah. Implementasi akad pada berbagai kegiatan bisnis berupaya untuk memberikan legal dan dasar hukum yang jelas. Tentu dapat dikatakan, jika akad juga mampu menjamin bentuk perjanjian yang harmonis bagi setiap pihak yang bertransaksi, tentu akad ini mampu diterapkan dalam berbagai kegiatan bisnis maupun ekonomi yang lain. Karenanya dapat dibenarkan bila dikatakan bahwa akad merupakan sarana sosial yang ditemukan oleh peradaban umat manusia untuk mendukung kehidupannya sebagai makhluk sosial.

Kegiatan bisnis yang dilakukan oleh BUMDes harus dapat dipertanggungjawabkan sesuai peraturan yang berlaku, tidak koruptif, akuntable, partisipatif, sustainable. Dan juga sebagai pengelola yang memiliki keyakinan kepada Allah, tidak cukup hanya aspek legal saja yang menjadi panutan. Pemahaman akan akad-akad ekonomi syariah juga menjadi sangat penting untuk menjamin bahwa kegiatan usahanya sejalan dengan hukum Allah agar usahanya mendapat berkah.

Sepertihalnya dalam BUMDes Mitra Sejahtera yang masih menggunakan tarnsaksi konvensiaonal. Sebagian masyarakat desa Kaotan merasa kirang puas dengan pelayanan porduk dan usaha bentukan BUMDes ini krena sebagaian besar dirasa merugikan bagi masyarakat kecil dan lebih menguntungkan bagi warga kaya. Terlebih lagi mayoritas warga desa Kaotan beragam islam tentu sangat menginginkan pengelolaan BUMDes sesuai dengan prinsip islam. Saat ini BUMDes Mitra Sejahtera beranggotakan 10 orang Sebagai pengelola yang diketuai oleh Bapak Nurholis. Bentuk kegiatan usahanya adalah jual beli makanan dan usaha penyewaan alat pertanian. sebagai keuta BUMDes, bapak Nurholis sanagt mengingikan adanya perubahan manajemen dan tata kekola BUMDes agar mampu diteri masyarakat dengan menggunakan Akad-akad syariah.

Maka tim pelaksana perlu sekali mengadakan Sosialisasi Akad-Akad Ekonomi Syariah Bagi Pengelola BUMDes Kaotan guna meningkatkan pemahamannya supaya kegiatan ekonominya selaras nilai-nilai dan prinsip ekonomi Islam. Pemaparan menggunakan media layar proyektor yang dibagi dalam beberapa materi. Yaitu pengertian ekonomi syariah, prinsip bisnis syariah, bentuk akad-akad syariah.

\section{METODE}

Pelaksanaan pengabdian dilakukan dengan tiga tahapan, di mana tahap pertama merupakan tahap 
persiapan. Pada tahap ini kelompok pengabdi melakukan survey pendahuluan untuk melihat kondisi perekonomian dan kegiatan usaha BUMDes Mitra Sejahtera. Dalam tahap ini dicari permasalahanpermasalahan yang dihadapi oleh BUMDes dalam mengembangkan bidang usaha yang dimiliki. Tahap selanjutnya merupakan tahapan pelaksanaan kegiatan pengabdian. Dalam tahap ini pengabdi melakukan kegiatan pelaksaan pengabdian sesuai dengan tema “ sosialisasi akad-akad syariah pada Badan Usaha Milik Desa (BUMDes Mitra Sejahtera) “. Tahap yang terakhir adalah tahap evaluasi. Pada tahap ini dilakukan evaluasi atas hasil yang telah dicapai oleh peserta. Masukan dan perbaikan lebih lanjut dapat dilakukan pada tahap ini.
Dan tahap selanjutnya dalah membuat laporan pengabdian dan artikel pengabdian untuk selanjutnya di submit dalam jurnal pengabdian masyarakat Pengabdian masyarakat yang tekah terakreditasi.

Pelaksanaan kegiatan Pengabdian Pada Masyarakat ini dikemas dengan menggunakan pendekatan workshop. Kegiatan dilakukan menggunakan metode ceramah, diskusi dan praktek di Badan Usaha Milik Desa Kaotan. Kegiatan ini dilakukan bukan hanya sekali tetapi melalui beberapa tahapan sesuai dengan materi yang telah di susun oleh pemateri. Adapun langkah-langkah dalam pelaksanan kegiatan pengabdian adalah sebagai berikut:

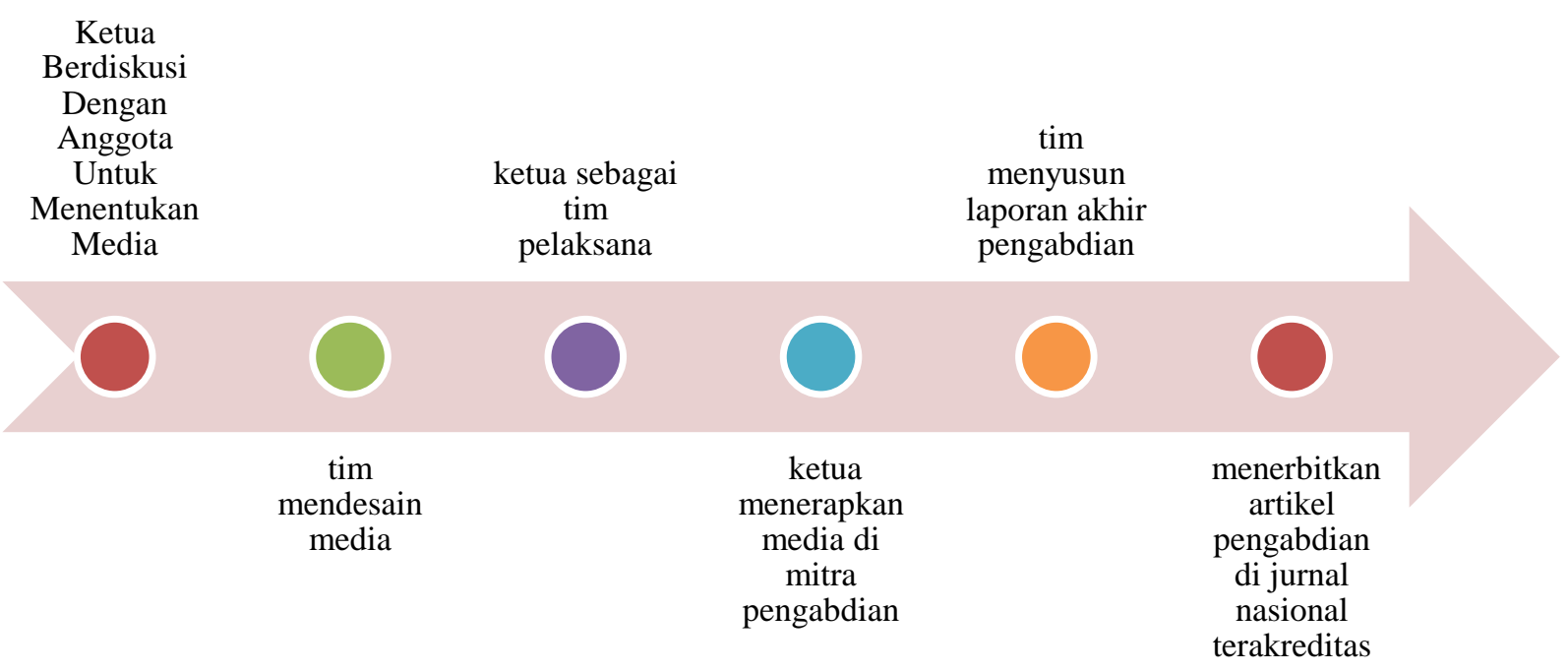

Gambar 1. Tahapan dan Langkah-Langkah Pelaksanaan Pengabdian

\section{HASIL DAN PEMBAHASAN}

\section{Profil Mitra BUMDes Mitra Sejahtera Desa Kaotan Banyuwangi}

Adapun pelaksanaan pengabdian ini telah bekerjasama dengan mitra BUMDes Mitra Sejahtera. Yang berada di desa Desa Kaotan Kecamatan Kabat
Kabupaten Banyuwangi. Dalam profilnya, BUMDes Mitra Sejahtera merupakan Badan Usaha Desa yang dibentuk dari hasil musyawarah secara mufakat oleh perangkat desa, badan musayawarah desa, dan tokoh masyarakat desa Kaotan. Berdasarkan hasil musyawarah tersebut maka disepakati didirikan Badan Usaha Milik Desa "Mitra Sejahtera” Nomor 07 Tahun 
2016 pada tanggal 20 april 2014 di Desa Kaotan Banyuwangi.

Dalam merancang progam Badan Usaha Milik Desa sesuai dengan pengembangan perekonomian masyarakat secara berkeseinambungan. maka BUMDes Mitra Sejahtera memiliki visi dan misi yang jelas dang kongkret. Adapun visi BUMDes Mitra Sejahtera yaitu : menjadi badan usaha milik desa (BUMDes) Mitra sejahtera dalam berupaya mewujudkan masyarakat desa kaotan untuk berkarya, dan berdaya saing dalam menggali potensi sumber daya alam dan sumber daya manusia untuk kepentingan bersama". Dalam menunjang keberhasilan visi, maka BUMDes Mitra Sejahtera memiliki misi sebagai berikut:

1. Menanamkan nilai-nilai Nasiolisme bagi masyarakat Desa Kaotan

2. Menumbuhkan sikap kebersamaan dan gotong royong.

3. Ikut serta memberdayakan masyarakat desa kaotan dalam perencanaan dan pengelolaan perekonomian.

4. Menerapkan rasa keterbukaan bagi masyarakat Desa Kaotan

5. mewujudkan unit lembaga perekonomian tingkat desa serta mampu memberikan pelayanan yang memadai terhadap kebutuhan masyarakat Desa Kaotan

Selama kurang lebih 5 tahun berdiri, BUMDes Mitra Sejahtera menjadi salah satu Organisasi Desa dengan pengelolaannya yang dibentuk berdasarkan forum musyawarah masyarakat secara demokratis. Dalam pengelolaannya, BUMDes Mitra Sejahtera memiliki struktur organisasi yang jelas berdasarkan musyawarah perangkat desa dan diatur dalam peraturan desa (perdes). Adapun perekrutan pengelola BUMDes Mitra Sejahtera dipilih setiap 5 tahun sekali atau sesuai dengan kebutuhan lembaga tersebut.

\section{Sosialisasi Akad-Akad Syariah di BUMDes Mitra Sejahtera}

Dalam perkembanganya, BUMDes sebagai salah satu bentuk usaha yang dirumuskan dalam musyawarah tingkat desa dengan tujuan memakmurkan masyarakat desa. BUMDes menjadi salah penopang kegiatan ekonomi masyarakat dalam lingkup desa. fungsi BUMDes secara dasar dapat digambarkan pada sektor permodalan, sektor sosial, dan sektor komersial. Peran BUMDes pada sektor permodalan tentu mampu memberikan pelayanan terhadap pinjaman maupun kegiatan simpanan yang dilakukan oleh masyarakat. pada sektor sosial, BUMDes hadir dalam memberikan kemudahan masyarakat dengan beberapa fasilitas dan usaha sosial yang dapat dijalankan oleh masyarakat setempat. Lalu pada sektor koimersial, BUMDes memiliki peran sebagai unit perantara bagi masyarakat dalam menjual hasil produk industry maupun usaha peertanian yang digeluti. Sesuai dengan tujuan pendirian BUMDes, maka dapat dismpulkan bahwa BUMDes memiliki tujuan diantaranya : (1) meningkatkan perekonomian dan pendapatan asli desa. (2) upaya menggali potensi desa dan masyarakat. serta upaya BUMDes dalam berkontribusi dala pengembangan kegiatan perekonomian desa (Ramadana.2013:75).

Pendirian Badan Usaha Milik Desa (BUMDes) dimaksudkan sebagai upaya menampung seluruh kegiatan di bidang ekonomidan/atau pelayanan umum yang dikelola oleh Desa dan kerja sama antar Desa. BUMDes dalam menjalankankegiatannya tentunya akan behubungan dengan pihak lain (klien). Maka dari itu,transaksi antara BUMDes dan klien harus memperhatikan hak dan kewajiban masing-masing pihak. Hak dan kewajiban dalam transaksi ekonomi diperlukan agar semua pihak yang terkait dapat memperoleh apa yang diinginkan, dan tidak ada pihak yang dirugikan.

Kegiatan sosialisasi akad-akad Syariah dilakukan dengan menghadirkan 10 orang pengurus BUMDES Mitra Sejahtera Desa Kaotan Rogojampi Banyuwangi. Pelaksana sengaja memilih pengurus BUMDES Mitra 
Sejahtera, karena pengurus BUMDES merupakan penggerak utama serta pemegang kebijakan dala BUMDES. Harapannya, secara lebih lanjut kegiatan sosialisasi ini tidak berhenti pada ranah pengetahuan para pengurus saja, namun secara lebih jauh dapat menjadi pertimbangan bagi pengurus BUMDES dalam mengambil kebijakan serta keputusan terkait produk dan pelayanan BUMDES.

Kegiatan ini diawali dengan pemberian pre test terkait akad-akad syariah. Pre test penting untuk dilakukan guna mengetahui sejauh mana tingkat pemahaman para pengurus BUMDES akan ekonomi Syariah secara umum dan akad-akad Syariah secara khusu. Setelah memberikan pre test, kegiatan PKM dilanjutkan dengan memberikan gambaran tentang ekonomi Syariah, prinsip akad, akad yang dilarang dan diperbolehkan dalam Syariah dan beberapa akad Syariah yang dimiliki oleh Islam. Setelah memberikan materi dan gambaran terkait dengan akad ekonomi syariah, maka selanjutnya para pengurus akan diberikan pos test, hal ini bertujuan untuk mengetahui sejauh mana perubahan pengetahuan pengurus BUMDES dibandingkan dengan sebelum mendapatkan pelatihan. Untuk lebih jelasnya proses kegiatan sosialisasi dapat digambarkan sebagai berikut:

\begin{tabular}{|l|}
\hline 1. $\begin{array}{c}\text { Pembukaan Dan Tujuan Pengabdian Masyarakat } \\
\text { Yang Diprakarsai oleh UM Jember }\end{array}$ \\
\hline 2. Memberikan Pre Test \\
\hline 3. Memberikan materi tentang prindip-prindip akad syariah \\
\hline
\end{tabular}

4. Memberikan Materi tentang Berbagai Jenis Akad Ekonomi Syariah

5. Memberikan Post Test

Gambar 2. Proses Kegiatan Sosialisasi

\section{Internalisasi akad-akad syariah dalam transaksi BUMDes Mitra Sejahtera}

Kegiatan ekonomi tentu harus berorintasi pada hasil dan manfaat serta tidak mengandung unsur tindakan dzhalim (pengaSetiap kegiatan ekonomi harus mengandung unsur manfaat serta tidak melakukan penganiayaan terhadap dirinya dan orang lain,sehingga kegiatan ekonomi dapat menciptakan kesejahteraan masyarakat secaramerata. Melakukan kegiatan ekonomi tidak diperbolehkan dengan melakukanpenipuan, perjudian, pemaksaan ataupun mengambil hakmilik orang lain dengancara-cara bathil.Badan Usaha Milik Desa (BUMDes) dapat menggunakan transaksi secara syari'ah dalam menjalankan usahanya. Hal ini karena di pedesaan masih kuatnilai-nilai kegotong-royongan (Dzikrullah,2016:90). Nilai-nilai tersebut menandakan bahwa masyarakat desa sangat peduli dengan kondisi yang terjadi pada oranglain, sehinga tidak akan melakukan sesuatu yang merugikan satu pihak saja.

Seperti yang telah dijelaskan sebelumnya, bahwa Badan Usaha Milik Desa (BUMDes) memiliki beberapa jenis kegiatan usaha. Kegiatan tersebut tentunya akan melakukan kegiatan transaksi (kesepakatan) dengan pihak lain. Seperti yang telah dibahas sebelumnya juga bahwa dalam ekonomi islam kegiatan transaksi yang melibatkan dua orang atau lebih harus ada jalinan ikatan (akad) yang jelas diantara pelaku akad. Pada bagian akad-akad ekonomi islam pada penelitian ini telah disebutkan dan dijelaskan akad-akad dalam ekonomi islam (transaksi secara syari'ah) (Abdurraman.2013:178)

Beberapa produk dan layanan jasa pada BUMDES Mitra Sejahtera Desa Kaotan Rogojampi Banyuwangi menggunakan akad jual beli dan persewaan alat-alat pertanian. Akad jual beli diterapkan pada jual beli makanan. Seperti yang telah dijelaskan sebelumnya bahwa BUMDES Mitra Sejahtera juga menggunakan akad persewaan alat-alat pertanian. Hal ini lumrah mengingat mayoritas penduduk Desa Kaotan Sebagian besar bermata pencaharian sebagai petani. 
Melihat dari beberapa akad yang digunakan, maka ada beberapa akad-akad Syariah yang dapat diterapkan pada BUMDES Mitra Sejahtera.

a. Jual beli makanan

Dalam hal jual beli makanan, maka pengurus pada BUMDES Mitra Sejahtera dapat menginternalisasikan nilai-nilai ekonomi Syariah dalam bentuk:

1) Bai' As-Salam

Akad Bai' As-Salam pada dasarnya merupakan jual beli pesanan. Dimana calon pembeli yang menginginkan suatu barang, akan memesan pada penjual dengan menyebutkan spesifikasi dan kriteria barang secara gambling dan jelas. Maka dalam hal ini, BUMDES Mitra Sejahtera dapat memberikan layanan kepada masayarakat untuk memesan makanan yang diinginkan baik yang sudah tersedia di BUMDES, maupun belum. Terhadap barang yang didinginkan oleh calon pembeli namun belum tersedia di BUMDES, maka pengurus BUMDES akan memesankan pada agen sesuai spesififkasi dan kriteria yang diinginkan oleh calon pembeli.

\section{2) Bai' al-Murabahah}

Akad Bai' al-Murabahah pada dasarnya merupakan jual beli sesuatu yang bernilai besar yang mana penjual membuat kesepatan dengan pembeli untuk mengambil besaran keuntungan yang diinginkan. Dalam hal ini berarti keuntungan yang diperoleh oleh penjual merupakan hasil kesepakatan antara pembeli dan penjual.jual beli ini biasanya dilakukan pada skala besar terhadap barang-barang yang relative sulit untuk didapatkan.

BUMDES Mitra Sejahtera dapat memposisikan sebagai sarana dan wadah bagi masyarakat yang ingin membeli barang dan makanan yang diinginkan masyarakat. Masyarakat yang ingin membeli suatu barang dalam skala besar dapat memesannya pada BUMDES dengan capaian keuntungan yang disepakati antara pembeli (masyarakat) dan penjual (BUMDES)

b. Persewaan alat-alat pertanian

Seperti halnya telah dijelaskan di atas bahwa BUMDES Mitra Sejahtera juga mengelola persewaan alat-alat pertanian. Islam juga telah memiliki akad-akad terskait sewa menyewa. Beberapa akad sewa-menyewa berdasarkan prinsip Syariah diantaranya:

1) Ijarah

Akad Ijarah merupakan konsep akad dalam Islam dalam hal layanan persewaan jasa maupun benda (property) dengan nilai sewa dan waktu yang telah ditetapkan dua belah pihak. Dalam hal ini, BUMDES Mitra Sejahtera dapat menentukan nilai sewa atas manfaat alat-alat pertanian beserta dengan tenggang waktunya.

\section{2) Ijarah Muntahiya At-Tamlik}

Akad Ijarah Muntahiya At-Tamlik secara sederhana merupakan sewa menyewa yang diakhiri dengan kepemilikan barang sewaan oleh penyewa. Dalam hal ini BUMDES dapat memberikan warna baru sewa menyewa alat pertanian dengan memberikan opsi pada penyewa bahwa barang sewaan dapat dimiliki sepenuhnya oleh penyewa di akhir masa penyewaan. Besaran biaya sewa yang dibayarkan penyewa pada tiap periodenya juga termasuk pembayaran berkala atas barang sewaan tersebut. 


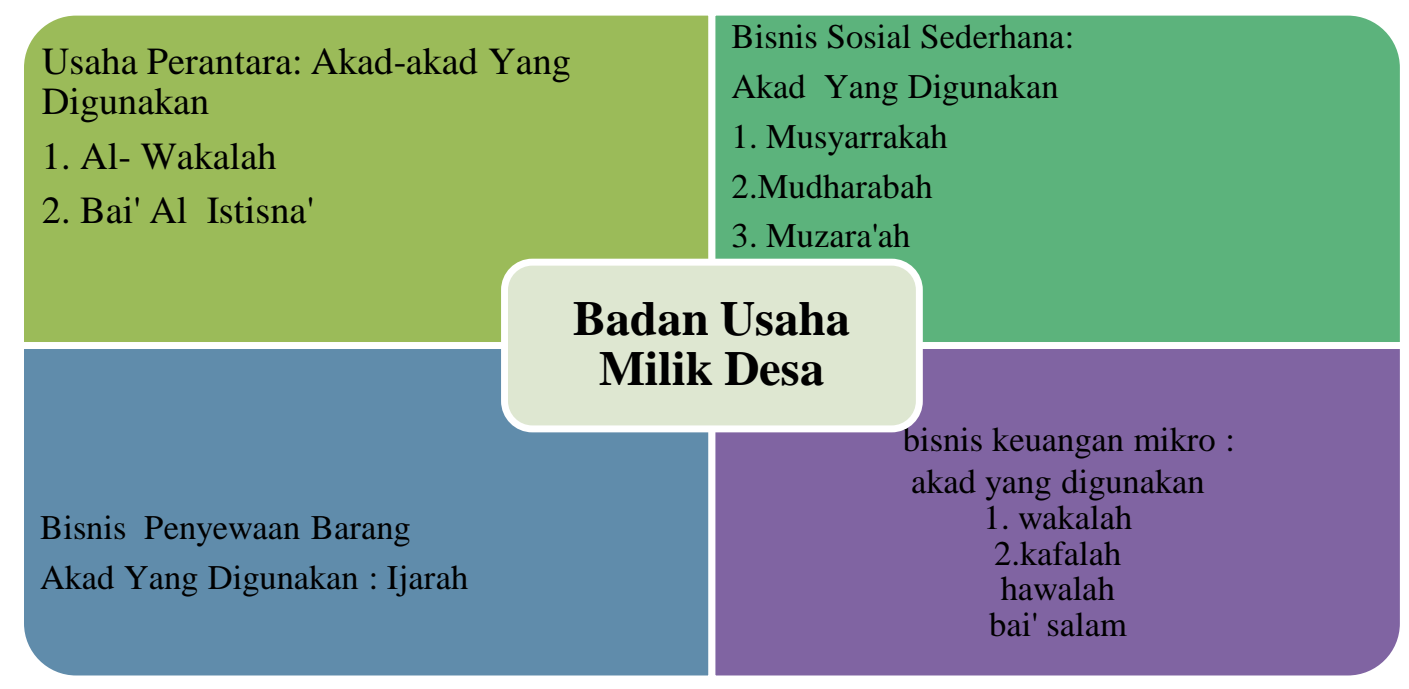

Gambar 3. Konsep-Konsep Usaha BUMDes Menggunakan Akad-Akad Syariah

Setelah proses pelaksanaan kegiatan pengabdian dilakukan, maka tim pengabdia melakukan kegiatan evaluasi hasil pengabdian. Kegiata evaluasi ini dilaksanakan sebagai upaya untuk mengukur pelaksanaan kegiatan pengabdian. Hasil evaluasi yang dilaksanakan dalam bentuk post test untuk menilai seberapa dalamkah pemahaman peserta pengabdian terkait akad-akad syariah yang dapat diimplemtasikan pada pengelolaan BUMDes Mitra Sejahtera.

\section{KESIMPULAN}

BUMDes Mitra Sejahtera secara operasional masih menggunakan akad konvensional. Sosialisasi akad-akad ekonomi Syariah pada BUMDES Mitra Sejahtera merupakan kegiatan pemahaman terhadap para pengurus BUMDES akan akad-akad ekonomi Syariah. Materi sosialisasi meliputi prinsip-prinsip akad ekonomi Syariah, hal-jal yang dilarang dan diperbolehkan dalam akad Syariah dan beberapa akad Syariah. Kegiatan sosialisasi juga berlanjut pada tataran pendampingan internalisasi akad-akad ekonomi Syariah. Adapun beberapa akad Syariah yang sesuai diterapkan pada BUMDES Mitra Sejahtera diantaranya adalah akad bai'
As-Salam dan Bai' al-Murabahah pada layanan jual beli makanan. Adapun pada layanan persewaan alat-alat pertanian, akad Syariah yang sesuai dan dapat dihunakan adalah akad ijarah dan ijarah muntahiya bit Tamlik.

Mayoritas BUMDes (bukan hanya BUMDes Mitra Sejahtera) yang menjalankan system operasionalnya berdasarkan prinsip konvensional. Upaya-upaya menerapkan system ekonomi Syariah menjadi system ekonomi nasional haruslah dimulai dari yang paling mikro, salah satunya BUMDES. Oleh karenanya, kegiatan-kegiatan sosialisasi seperti halnya di atas perlu untuk dilanjutkan.

\section{UCAPAN TERIMA KASIH}

Tim pengabdian kepada masyarakat mengucapkan banyak terima kasih kepada BUMDes Mitra Sejahtera yang dalam kegiatan ini banyak membantu dan mendukung sebagai mitra dalam proses pelaksanaan kegiatan.

\section{DAFTAR PUSTAKA}

Abdurrahman,Nana Herdiana.2013.Manajemen Bisnis Syariah Dan Kewirausahaan.Bandung:CV Pustaka Setia 
Journal of Community Development, Vol. 2, No. 1, Oktober 2021

E-ISSN: 2747-2760

DOI : $\underline{10.47134 / \text { comdev.v2i1.31 }}$

Apriantono, Eko.2016. Memajukan Ekonomi Desa Melalui BUMDes. Artikel ini di download di : http://binaswadaya.org/bs3/memajukan-ekonomidesa-melalui-BUMDes/ pada tanggal 12 November 2020

Attoillah.M.A.2013. Ekonomi Islam: Transaksi dan Problematikanya. Jurnal Wacana Hukum Islam Dan Kemanusiaan.Vol.13.No.2

Peraturan menteri desa, Pembangunan Daerah Tertinggal Dan Transmigrasi Republik Indonesia Nomor 4 Tahun
2015 tentang Pendirian, Pengurusan dan pengelolaan BUMDes

Ramadana, Coristya Berlian, dkk.2013. Keberadaan Badan Usaha Milik Desa (BUMDes) Sebagai Penguat Ekonomi Desa. Jurnal Administrasi Publik (JAP) Vol.1.No.6

Dzikrullah dan Eka Permata, A.R.2016. Sinergitas Baitul Maal Wa Tamwil (BMT) dengan Badan Usaha Milik Desa (BUMDES) Sebagai Alternative Penguatan UMKM Masyarakat Pedesaan. Jurnal DINAR Ekonomi Syariah.Vol.1. No.1 